\title{
Management Accounting Change in Family Firms: The Ambivalent Role of the Successor
}

\author{
Annalisa Sentuti ${ }^{1} \&$ Francesca Maria Cesaroni $^{1}$ \\ ${ }^{1}$ School of Economics, Department of Economics, Society and Politics, University of Urbino Carlo Bo, Urbino, Italy \\ Correspondence: Francesca Maria Cesaroni, School of Economics, Department of Economics, Society and Politics, \\ University of Urbino Carlo Bo, via Saffi 42, 61029, Urbino, Italy. Tel: 39-722-305-528. E-mail: \\ francesca.cesaroni@uniurb.it
}

Received: May 20, 2020

doi:10.5430/jms.v11n2p18
Accepted: May 29, 2020

Online Published: May 30, 2020

URL: https://doi.org/10.5430/jms.v11n2p18

\begin{abstract}
Why does a process of management accounting change (MAC) that started with the best premises for a successful conclusion stop? What could be the causes of failure? In the last few decades, several authors have tried to answer these questions in the field of MAC by adopting different theoretical frameworks and offering various responses. However, few contributions have dealt with this theme from the family's perspective, and they haven't considered the specific challenges concerning such firms, like those connected to the succession process.

However, few contributions have dealt with this theme from the perspective of family and considering their specific characteristics and challenges, as in particular the succession process. To fill this gap, this paper explores the relationship between MAC and the succession process aiming to answer the question: "How can a successor influence the start, development and final outcome of a MAC process in a family business?" Using a longitudinal case study, the paper explores an Italian family firm in which a MAC and a succession process started simultaneously. However, despite all the best premises for its development and implementation, the MAC process was interrupted. The analysis focuses on the successor and his goals and motivations to better understand which role he assumed in the MAC process. Findings suggest that a successor can play an ambivalent role. He can be a key agent in promoting and triggering a MAC process in family firms, but he can also become a major obstacle to the process of change when his personal objectives and interests prevail over the company's needs.
\end{abstract}

Keywords: management accounting change, management accounting, family businesses, succession, longitudinal case study, interventionist research approach

\section{Introduction}

In the last few decades, in the field of management accounting change (MAC) studies, many authors have tried to identify which factors may favour or hinder the introduction and implementation of new management accounting systems (MA) (Zoni et al., 2012). However, few contributions have addressed these issues when it comes to family businesses and considering their specific characteristics (Prencipe et al., 2014).

According to one of the most acknowledged definitions, a family firm is a "business governed and/or managed with the intention to shape and pursue the vision of the business held by a dominant coalition controlled by members of the same family or a small number of families in a manner that is potentially sustainable across generations of the family or families" (Chrisman et al., 1999).

Family businesses are the prevalent form of organisation across the globe and represent about 70-90\% of all firms worldwide (Zellweger, 2017). For instance, according to the European Family Businesses Federation, in Europe, they account for $75 \%$ of companies in Italy, Germany and France, 65\% in the UK and Norway, $80 \%$ in Finland and reach $85 \%$ in Spain.

In family business studies, the main attention has been devoted to succession, governance, performance and the objectives that characterise these businesses (Sharma, 2004; Moores, 2009; Salvato \& Moores, 2010). Results from these studies have allowed gaining a better understanding of family firms and affirming that the involvement of the family in the ownership, governance and management of the business has a significant influence on decision-making processes, organisational processes and business behaviours. 
However, within family business studies, the subject of MA has been largely neglected. On the other hand, the literature on MA paid little attention to family businesses, giving priority to public companies (Salvato \& Moores, 2010) and other types of businesses in which the family influence is ignored (Quinn et al., 2018).

Recognising the relevance and uniqueness of family firms, some authors have pointed out that the binomial "MA" and "family businesses" have not been adequately analysed in either of the two fields of research and have urged scholars to bridge this gap, furthering empirical investigations on this topic (Salvato \& Moores, 2010; Prencipe et al., 2014; Senftlechner \& Hiebl, 2016; Heinicke, 2018; Quinn et al., 2018). From this perspective, family firms are considered a unique and singular setting (Salvato \& Moores, 2010), in which "family-specific" determinants can influence the technical characteristics of adopted MA systems (Craig \& Moores, 2005), the criteria and objectives underlying the design of such systems, their use (Quinn et al., 2018), as well as the MAC processes, in terms of decision-making processes, motivating factors, implementation practices and consequences of change (Salvato \& Moores, 2010) in various ways.

Thus, in recent years, some scholars have started investigating MA in family businesses (Giovannoni et al., 2011; Bracci \& Maran, 2012; Hiebl et al., 2013; Stergiou et al., 2013; Leotta et al. 2017; Hiebl \& Mayrleitner, 2019; Quinn et al., 2020). Their studies have confirmed that family firms choose, implement and use MA systems differently than non-family businesses. However, these searches remain limited and do not allow for a thorough understanding of the phenomenon.

The research that has explored MA in family businesses involved in a succession process is even more limited (Giovannoni et al., 2011; Bracci \& Maran, 2012; Songini et al., 2013; Leotta et al., 2017). Succession is considered one of the most critical challenges that family firms face (Le Breton-Miller et al., 2004; De Massis et al., 2008). It represents a crucial phase in their life cycle, during which the logic of the business is often overwhelmed, or very much conditioned, by the objectives, preferences, ambitions and personal choices of the predecessor and successor, family relationships and the dynamics between family and business. These factors can also largely influence the MAC processes, which can be initiated and evolve according to different logic rather than the rational business logic. According to Stergiou et al. (2013), in fact, the decisions that family firms make regarding the MAC processes are not always made "by 'economically rational agents' using economic calculus alone."

Kasurinen (2002), starting with Cobb et al. (1995) and Innes and Mitchell's (1990) previous works, identified some factors that favour the start and the implementation of a MAC process. He also highlighted the existence of possible barriers that could hinder or even cause the implementation of the process in the firm to fail. Namely, in his model, the author identified influencing factors, such as motivators, facilitators and catalysts that aim to create the potential for change, and drivers for change, i.e., factors that contribute to the implementation and conclusion of the process. In the latter group, key roles could be played by the leader of change, who should take over the reins of the process and promote its advancement, and by the momentum of change, that is, the presence of the expectation of continuing change in the company. Barriers to change generally occur during the implementation phase, hindering or preventing the conclusion of the process. Kasurinen identified three types of barriers: a) confusers, which create confusion between objectives and priorities from different views on change; b) frustrators, which inhibit and/or discourage change; c) delayers, which slow down the progress of the process.

This model, while representing a useful theoretical framework for interpreting MAC processes, pays minimal attention to an essential element of the change process, namely the role that individuals involved in the process can play. Kasurinen's model mainly focuses on external factors or the business context that may favour or hinder the process of change: on the one hand, the external factors, i.e., the market and the socio-economic context, which generate most of the pressures that then lead to the process of change (e.g., globalisation, innovation, technology, competition, etc.); on the other hand, the business context, i.e., the structural conditions of the company, which may foster (e.g., organisational structure, strategies, partnerships, etc.), or hamper (e.g., organisational culture, uncertainty, inadequate information systems, etc.) the process of change. In the model, individuals can act as catalysts for change in the early stages of the process, or as change leaders in the subsequent stages (Cobb et al., 1995). However, the model does not consider motivations that could push an individual to take on such roles. As a result, the model has limited ability to explain the reasons that can guide actors in acting on change.

Other authors have focused on the key role that individuals, as agents, can play in a MAC process (Zoni et al., 2012), underlining that the success of change depends on the "promoters of change" and in particular on the power and trust, they have in the organisation (Hiebl et al., 2013). Further studies have shown that MAC processes are strongly influenced by the interests of the actors involved and by their perception and interpretation of the context conditions/contradictions and critical external events that can influence the organisation (Sánchez-Matamoros et al., 
2014). The change, in this perspective, is not only the result of external factors and/or business factors (Zoni et al., 2012), but it is also the consequence of an interaction between conditions/requirements/factors related to the business context and factors related to the interests/motivations/perceptions of actors involved in a MAC (Stergiou et al., 2013).

In family businesses involved in a succession process, a major player is undoubtedly the successor (Zellweger, 2017), who can also play a key role in promoting and introducing new MA practices (Leotta et al., 2017). Therefore, evaluating the individual perspective of the successor can be particularly important when trying to understand the peculiarities of a MAC process that occurs in the specific organisational setting of a family business. In this context, successors could apply their own beliefs, goals and reasons to the process of change, which is why we wonder whether potential successors' "personal" interests and motivations will condition their role in the MAC process. It is also possible that their interests and motivations are not inspired by economic rationality, as often happens in family businesses (Stergiou et al., 2013), but, on the contrary, are dictated by more subjective reasons and priorities (Leotta et al., 2017).

Starting from these premises, this paper aims to fill the gap identified in studies on MAC (which ignore the specificities of family businesses) and the literature on family businesses (which has devoted little attention to the analysis of MAC processes). Specifically, this study focuses on the role of the successor in MAC processes and intends to answer the following research question: "How can a successor influence the start, development and outcome of a MAC process in a family business?"

\section{Method}

\subsection{Methodological Approach}

To answer the research question, a qualitative approach based on a case study was adopted. This approach is particularly valuable for the investigation of MA in the context of family businesses (Scapens \& Bromwich, 2001; Salvato \& Moores, 2010; Stergiou et al., 2013; Prencipe et al., 2014), especially if, as in our case, the aim is to investigate "why and how certain accounting phenomena occur and unfold over time", as suggested by Salvato \& Moores (2010).

Notably, this article presents a longitudinal case study that allowed the two Authors of this paper - hereafter the Authors - to analyse a MAC process in a family business involved in a succession process with a long-term perspective. Particular attention was paid to the figure of the successor and his objectives, aims and ambitions, to understand the role he played in the start, evolution and conclusion of the process of change.

The case study was conducted with the recommended interventionist research approach, which has recently become common practice in MA studies (Jönsson \& Lukka, 2007; Suomala et al., 2014).

The case study was conducted with an interventionist research approach, the use of which is suggested and recently spreading in MA studies (Jönsson \& Lukka, 2007; Suomala et al., 2014). This approach is characterised by the particular relationship that is established between the reality under investigation and the researcher: the latter is not a simple observer in ongoing practices but is directly involved in the reality under investigation, in which they plays an active role, contributing to the evolution of the situation (Jönsson, 2010). Such involvement, undesirable in other research approaches, is the "key strength" in this interventionist research approach (Jönsson \& Lukka, 2007).

The Authors were actively involved in the working team, which, for about two years, was devoted to the project. The latter, however, stopped before the development and implementation phase of the newly designed MA system. Personal involvement in the working group and the empirical evidence directly acquired allowed the Authors to propose a critical interpretation of the investigated process (Jönsson, 2010; Suomala et al., 2014).

\subsection{The Analysed Case}

The analysed case concerns an Italian medium-sized family firm that carried out its succession process and MAC simultaneously. Despite all the best premises for its implementation and development, the MAC process suddenly stopped without a clear reason. This is an extreme case (Eisenhardt \& Graebner, 2007; Miles et al., 2014) that is characterised by an "unusual manifestation of the phenomenon" such as, in this case, a notable failure (Patton, 2002). In fact, it describes a case of a MAC process that stopped before its conclusion, even though it had, up until its failure, been carried out successfully and with the great appreciation of the company's top management team.

This circumstance makes the case particularly useful to investigate the role of the successor in influencing the evolution of a MAC process and to identify the underlying motivations behind his behaviour and choices. The case also responds to Giovannoni et al. (2010), who call for further empirical research to understand how succession and 
MAC can influence each other in family businesses better.

\subsection{Data Collection and Data Analysis}

In line with the interventionist research approach, the Authors had a privileged position while following the entire evolution of the process; as a result, they collected a rich amount of data, materials and information.

The analysis covered a period of about 20 months, from June 2013 to February 2015. During this period, the Authors acted as researchers/active actors (Jönsson \& Lukka, 2007), collecting empirical data from different sources: a) direct observation and field notes related to working group meetings; b) minutes of working group meetings; c) semi-structured interviews with the members of the working group and top management team; d) balance sheets and other company documents; e) e-mails and informal conversations with the members of the working group and top management team.

Data analysis was carried out by adopting an iterative approach. The research question guided the analysis of the empirical evidence and the definition of the first critical interpretation. As the analysis further developed, this initial framework was enriched and modified, combining theoretical considerations and empirical observations dynamically. The theory provided initial guidelines for the interpretation of the case, while empirical data provided stimuli and suggestions for developing new explanations, leading to the formulation of a definitive interpretation (Emerson, 2004; Nordqvist et al., 2009).

In the following paragraphs, a description of the analysed case is presented, followed by the analysis and discussion of the main results.

\section{Case Study and Results}

\subsection{The Empirical Context}

Buxter Ltd is a medium-sized family business that was founded 20 years ago. Since its establishment, the company has shown a strong propensity for innovation and R\&D, which has led to rapid growth (around 250 employees and $€ 60$ million in turnover) and a strong presence in international markets. At the same time, the organisational structure has also been progressively modified, with an increasing decentralisation of decision-making and the involvement of numerous managers. The latter brought with them many qualified skills, crucial to efficiently control an increasingly complex company and sustain its competitive advantage.

A few years ago, the production process was profoundly restructured based on lean production principles (Krafcik, 1988; Womack et al., 1990). Consistent with this approach, the process and layout of the plants were reorganised, and the production activities were divided into value streams (Womack \& Jones, 1996; Hines \& Rich, 1997; Womack, 2006), in order to reflect the processes through which the company creates value for customers. Some indicators were also introduced to monitor the efficiency of production processes and product quality (e.g., throughput time, number of returns and rejects). Weekly meetings were also scheduled with workers to discuss and solve the main production issues together. These changes resulted in significant improvements in the company's production performance: stock levels progressively reduced; product quality increased; production flows became faster and more efficient.

\subsection{The Teamwork}

The promoter of the process of MAC in Buxter was the founder's son, the aspiring successor of the family business. With a degree in engineering, before joining Buxter, he worked for some years in other companies, mainly dealing with management control. He then took over his father's role as CEO of one of the companies in the holding controlled by his family.

In June 2013, the founder's son approached the two Authors and proposed that they collaborate with him to design a new MA system to be implemented at Buxter. The reasons for this decision were explained at the first meeting, which was also attended by a financial advisor, one of the company's historical consultants. During this meeting, the founder's son explained that, from his point of view, there was an urgent need to redesign Buxter's MA system since the existing one had become inadequate in light of the important changes that had occurred in the company in recent years.

The father's son went on to explain that Buxter had recently incorporated the company that he had led before as CEO. They - his father and Buxter's top management-were willing to carry out this operation to focus the group's energies on the main business, in the high-tech industry and with high growth and development potential, and at the same time to progressively leave the incorporated company, since the latter was located in a mature industry, with limited development potential. This operation led to a further increase in Buxter's size and diversification of its 
businesses, which resulted in a significant reorganisation of the company, involving production, logistics, organisation and governance.

According to the founder's son, all these changes had revealed the company's lack of management systems. They had made it necessary and urgent to introduce an adequate MA system, consistent with the new competitive conditions and the new information needs of the company. These reasons were confirmed by the financial advisor, who explained to the Authors:

"Buxter doesn't really have a management control system. There are many different systems and tools introduced at different times and by different people. These systems produce useful information to monitor and control some company activities and results, but they are very fragmented, partial and not connected. Conversely, Buxter needs an integrated system that covers all areas and meets all needs."

The financial consultant also informed us that the company did not have a real controller: the responsibility of MA was in the hands of the General Manager (also CEO of the company), supported by a collaborator, who was in charge of providing the information requested on each occasion, and by some external consultants. The financial advisor also explained other reasons, not mentioned by the founder's son:

"We can't deny that behind all this is also the intention to create a new position for him [the founder's son], who needs to understand what he's going to do in Buxter. [...] Buxter doesn't have a controller, and he has the right skills and experience to fill this role. That's why we want your help. We want him to be able to propose an effective system that is consistent with the needs of the company but also innovative and in line with the latest trends in management accounting and control."

The founder's son confirmed this and admitted:

"I have gone from everything to nothing. Until yesterday, I was the CEO of a company, and now I'm just a minority shareholder in Buxter. I don't have any role at the moment, and I have to start all over again."

The financial advisor and the founder's son, therefore, proposed that the Authors set up a working group, which would also include another advisor - a management engineer — who had already supported the company in the recent reorganisation of the production process. The Authors accepted and showed their willingness to collaborate with consultants to design a new MA system for Buxter. At the same time, the founder's son and the financial advisor would have submitted the project to Buxter's CEO and the funder (also board chairman), to get their formal approval and thus start the work. This approval came a few weeks later and the project was fully endorsed by the company's founder and General Manager. Thus, the working group formally created and started the project in October 2013.

\subsection{The MAC Process}

The first meetings of the working group were mainly dedicated to describing the history of the company and its current situation to the two Authors: organisation, product range, markets, strategies and competitive position. Particular attention was paid to innovations in the production process and the adoption of lean production principles.

Afterwards, the current MA system and its consistency with the company's information needs were analysed. At the end of this analysis, the misalignment between business needs and existing systems was immediately clear to everyone, and all the group members agreed on the need to define a work plan starting from the identification of the company's information needs. This need was confirmed by the General Manager during a meeting with the working group when he said:

"Buxter has grown quickly, and now the need for a new, more sophisticated and more effective MA system has become evident. This is something we have neglected until now, but now it is time to think about it."

The group defined a three-step process: start-up, design and implementation. In the start-up phase, the aim of the working group was to carry out a theoretical survey of the most innovative MA approaches, in order to select the system most consistent with the company's needs. The design phase had three main objectives: to map out the MA systems and tools already used in the company; to create a first draft of the new MA system; to simulate the functioning of the new system. The implementation phase aimed at developing the new system and ensuring its feasibility. The start-up phase took place from November 2013-April 2014. During this period, the members of the working group studied the most recent literature on MA, to identify the most consistent model for the company's information needs.

At the end of this analysis, they agreed that lean accounting (Maskell, 2000; Kennedy \& Brewer, 2005; Kennedy \& Huntzinger, 2005) was the MA's most appropriate approach for Buxter, as it was able to correctly measure costs and financial performance of the value streams mapped out in the company. In fact, the company had already introduced 
the principles of lean production. Therefore, the organisational and logistical conditions necessary for the effective adoption of lean accounting already existed (Johnson, 2006; Maskell \& Kennedy, 2007). The choice of lean accounting was shared not only by the Authors but also by the financial advisor, who stated:

"Continuing to use traditional cost management systems, in a company that has long adopted the logic of lean production, causes a substantial misalignment between what would be important to measure and what is really measured." The other consultant also had the same opinion: "A few years ago the company made a precise choice, adopting the principles of just in time and lean production. It was an important choice that required commitment and work, but we have always been convinced of its importance. I think we should now make a similar choice with regard to the control system because the company needs a modern and advanced system."

The group then moved on to the development phase. Starting from available historical data, a simulation of the value stream costing (VSC) approach began, and a value stream profit and loss statement were developed (VSP\&L) (IMA, 2006; Maskell \& Baggaley, 2006).

Up to that point, the group did not have any problem; a stimulating and fruitful collaboration had developed among the members of the group. The skills of each member were perfectly complementary, and the agenda and main decisions had always been unanimously shared. Thanks to these favourable conditions, the group progressed easily in developing the project and their results were gradually presented to the founder and the CEO.

The design phase was completed in November 2014, when the final architecture of the new MA system was formally presented to the founder and the General Manager and received their approval. Both expressed very positive opinions about the proposal, which was considered effective and in line with Buxter's requirements. The founder said:

"The system you designed perfectly reflects our needs. When the system is up and running, many of the problems we've had so far will be solved."

The General Manager also appreciated the consistency with the lean philosophy adopted by the company and the information needs resulting from a production process organised and managed on the basis of these principles:

"I very much agree with this proposal, especially because it is in line with the decision we made a few years ago to introduce the principles of lean production to our plants. I think this is the right way forward."

\subsection{The Process Interruption}

Encouraged by the consensus received, the members of the group began to think about the next steps for the development of the new system and gradually implementing it. With this goal in mind, the group met a few times in December, with the intention of meeting again in January 2015 to continue the project until its conclusion.

In January, the Authors contacted one of the consultants to ask for updates and schedule subsequent meetings. However, they received a completely unexpected response. The consultant informed the Authors that the founder's son was no longer interested in following the working group because the General Manager told the founder's son that he had to do a training course at the company to acquire knowledge and skills consistent with the role he was going to assume in the future. As the consultant pointed out, in fact, the founder's son was expected to take on the position of controller in the general management staff. However, he added:

“... before acquiring that position, the General Manager planned a long learning process (at least 18 - 24 months) that included a series of projects to be developed in various areas of the company, mainly production and sales. At the end of this process, he would take over the position of controller, and at that point, we would evaluate the development of the new MA system."

This interruption took the Authors by surprise, mainly because the General Manager's new program was not at all in line with the scenario envisaged up to that moment, in which the change of the MA system had been considered a priority. The Authors expressed their perplexities and proposed to continue working according to the established schedule even without the direct involvement of the founder's son, who until then had actively participated in the working group. The consultants agreed, but in fact, the project was interrupted for an unspecified period. No indication for its continuation came from the top management. Moreover, although the project was not definitively and officially abandoned, it has remained in a stand-by for several years. In 2017, the founder's son completed his learning process and assumed the role of controller. Only after about 3 years in the role, the successor decided to take over the project and started the implementation phase according to the final architecture of the new MA system designed by the working group. 


\subsection{Open Issues}

The unexpected epilogue of the project raised several questions, and it revealed several contradictions that had not emerged in the previous phases. Up to that moment, in fact, the project seemed to present all the necessary characteristics to be carried out and concluded successfully:

- the project had been designed to meet a need that that company deemed urgent and crucial;

- the company's leaders had been satisfied with the work carried out and had given their full approval to the MAC project;

- the working group had shared the project's goals and design and had been perfectly aligned with how they were going to accomplish it.

Against these circumstances, all in favour of the continuation of the project, however:

- the founder's son left the group, neglecting the project, despite the fact that he had been its promoter and despite his commitment until then;

- no other member of the company took over his position in the working group;

- the latter was not formally authorised by any representative of the company to carry out the project even in the absence of an internal component.

Ultimately, what had initially been presented as a priority for the company, in the light of these recent events, looked like a decidedly secondary need. On the other hand, the exit of the founder's son from the group brought to the forefront the importance of his role and motivations, whose centrality to the advancement of the project seemed much greater than what had appeared in the first instance.

\subsection{The Role of Successor}

The previous reflections and the perplexities raised by the unexpected interruption of the project led the Authors to reread the entire process, focusing in particular on the role of the founder's son during the various phases of the project and the reasons behind his decision to start the project and, subsequently, to abandon it.

In the start-up phase, the founder's son undoubtedly played a key role, acting as a catalyst for change (Innes and Mitchell, 1990). In fact, he had the idea of redesigning the MA system, also involving a group of external consultants and experts. The founder's son also became the promoter and supporter of the change process, persuading his father and the General Manager of its urgency and persuading them to invest money to engage a group of consultants that would be in charge of the project. However, regarding the reasons underlying the founder's son's behaviour, a more careful analysis of the evolution of the process leads to the identification of two orders of reasons: on the one hand, business reasons, explicitly stated during the project start-up phase and shared with the other actors, and on the other hand, personal reasons that were not clearly revealed.

Behind the manifest reason - to renovate the MA system and satisfy the company's information need - the epilogue of the project revealed a less evident and apparently secondary motivation, due to the will of the founder's son to carve out a new role for himself in the family business after the incorporation of the company he had previously directed. After the merger the founder's son had been left without a formal position within the main company- $I$ have gone from everything to nothing" - and for this very reason he needed to redefine his role and demonstrate his skills, gaining credit above all in the eyes of the General Manager. From his point of view, the introduction of a new MA system was intended to enable his entry into the company, where he would have acted as a controller. This objective did not turned out to be secondary at all, though it was apparently overshadowed and briefly mentioned during the first meeting, when, after the description of the company and the need to renew the MA system, one of the consultants cited the need of the founder's son "to understand what he is going to do at Buxter."

Therefore, this reinterpretation of the process reveals that the motivations of the founder's son acted as real "triggers of change" (Zoni et al., 2012) and played a much more influential and decisive role than the motivations related to the company's situation. The latter, in fact, proved to be much less urgent and high-priority than explicitly stated. Although important, the company's needs would not have been sufficient to trigger the process of change on their own. Only the commitment and first-hand involvement of the founder's son allowed the project to reach the design stage. However, the founder's son's interest in the project vanished at the beginning of the implementation phase, and his driving role stopped. The reason is that the start of the implementation phase coincided with the beginning of the training process of the founder's son alongside the General Manager. At that point, the need to renew the MA system — even though it was indeed unchanged and had never been denied-explicitly proved to be a minor priority 
also for the company, so much so that the top management put the project in a stand-by condition, postponing it until the conclusion of the training process of the successor candidate.

\section{Discussion and Conclusions}

The previous paragraph describes the experience of the Buxter family business involved in a MAC process. The analysis of the various phases of the process - from its start-up to its subsequent interruption - has provided very useful information to answer the research question and identify what the role of the successor in initiating and influencing the evolution and outcome of a MAC process in a family business can be. Findings suggest that the successor can be a key agent in promoting and triggering a MAC process in family firms, but he can also become a major obstacle to change if his objectives and interests prevail over the reasons related to the organisation and the contextual conditions.

Specifically, with regard to the start of the MAC process, findings confirm that the presence of an agent acting as a promoter of change is essential to launch the process. Contrary to prior research (Zoni et al., 2012) pressures from the competitive context or the general environment did not drive the start of the MAC at Buxter. The central role was played by an individual - in this case, the founder's son-who triggered the process of change, motivated by the desire to achieve personal goals that clearly emerged. In fact, the founder's son saw the launch of the MAC project as a "tool" to achieve his goals: to find his way within the new company and legitimise his role as a potential successor within the firm. Therefore, from this point of view, the case confirms what has been stated by other scholars who have underlined the major role of actors acting as catalysts (Kasurinen, 2002) or triggers (Zoni et al., 2012) of the change process.

The case also shows that the structural and organisational conditions, linked to the company's need to adopt a new MA system, were not sufficient to launch a MAC process by themselves. This does not mean that these motivations were completely irrelevant. On the contrary, in the case study presented in this paper, structural and organisational conditions played an important role, as they enabled the founder's son to strengthen and motivate his proposals. Without them, his personal motivations would not have been able to trigger an effective change process. In other words, to be able to pursue his real, initially latent goal, the successor's son "used" the organisational conditions to give the whole working team a strong and shared goal. This factor reinforces that, in the analysed case, the real "trigger for change" was internal and personal. In this sense, the study confirms that structural factors are not always sufficient to trigger change since the intervention of the agent is indispensable to interpret and evaluate the context and then act accordingly (Stergiou et al., 2013).

The successor's personal motivations and goals influenced not only the start-up phase but also the subsequent stages of the process (Figure 1). In fact, the process was stuck and lost its driving force when the successor reached his main goal; as a result, his motivation to continue the project vanished. Moreover, this happened even though the organisational motivation, shared and explicit, had remained valid, but evidently less "urgent" than it appeared at the beginning. The "change of course" of the successor, the redefinition of his programs and his exit from the working group resulted in the interruption of the process of change, which stopped even before fully entering the implementation phase. Therefore, in the analysed case, these factors acted as barriers as they hindered the progress of the change. Resuming the Kasurinen model (2002), these barriers took on the function of delayers, as they effectively interrupted the development of the new management control system, postponing its continuation. Compared to the Kasurinen model (2002), however, the case analysed shows that barriers cannot only intervene in the implementation phase (e.g., in the form of resistance to change within the organisation) but can also occur earlier. In fact, in the examined case, barriers appeared at the beginning of the implementation phase.

Findings also provide further insights into the leader of change's influence. In this respect, Cobb et al. (1995) have stated that the "dual-role of individuals as catalysts and leaders was crucial to the change process [...]. As catalysts, they initiated the change process, but without their leadership role the change process may have faltered in the face of the barriers". In this study, the successor's role evolved throughout the process, from catalyst and promoter in the start-up phase to the main obstacle to change in the implementation phase. The successor's attention, in fact, shifted to other areas and his role as a leader disappeared. In this sense, the project was instrumental in achieving the personal objectives of the successor, which were fulfilled. However, this then prevented the change from manifesting the potential and benefits it could have brought to the company. Therefore, the individual perspective of the successor-agent prevailed over the structural conditions of the family business. 


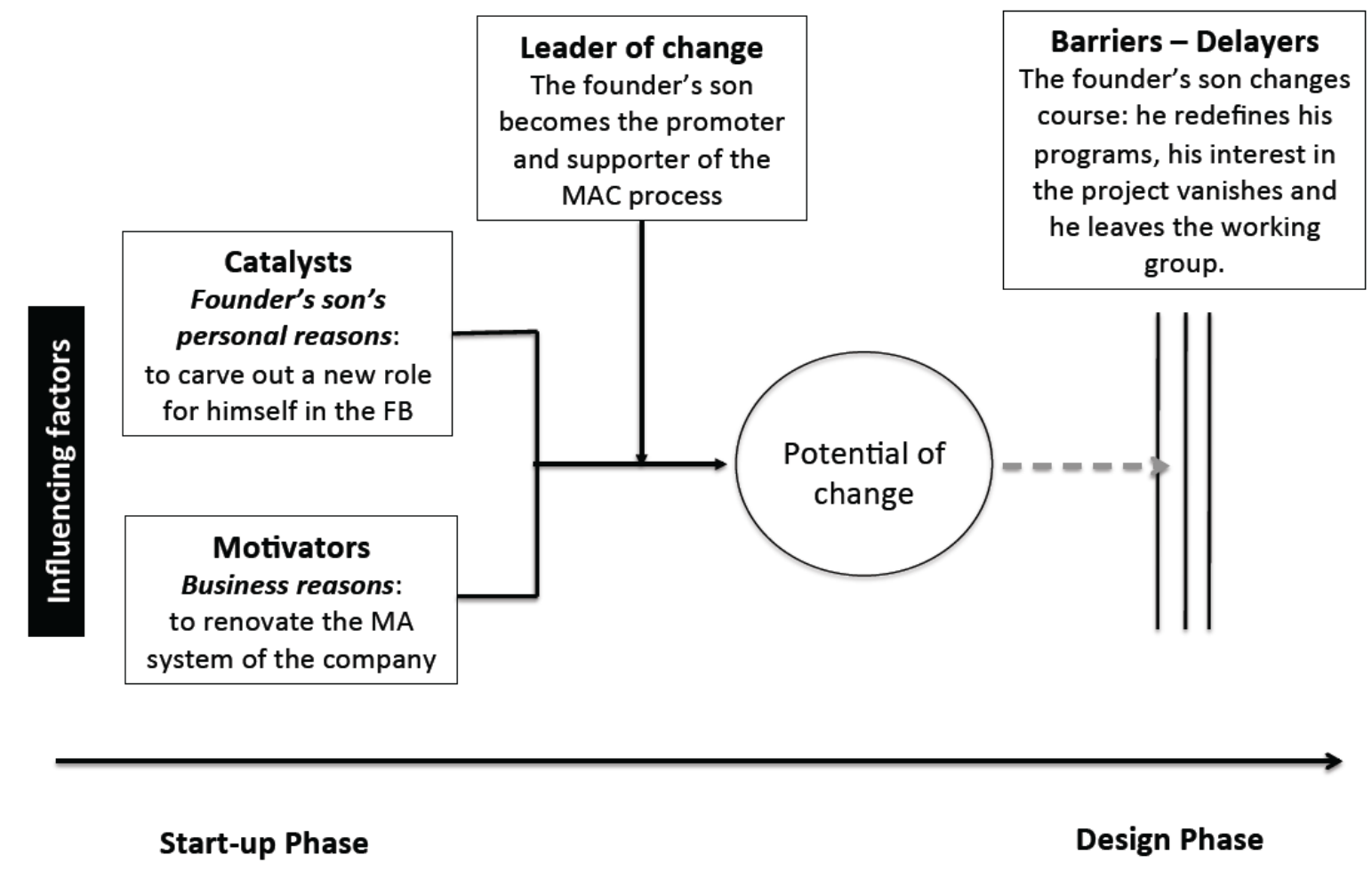

Figure 1. The ambivalent role of the successor in the management accounting change process

In conclusion, this paper contributes to the literature on MAC by providing four theoretical insights. First of all, the paper enriches prior studies on the interaction between agent and structure in MAC processes by deepening the analysis of a peculiar context, i.e., the family firm, which presents some specific characteristics that cannot be ignored in the definition of a MAC process, and the role of a particular agent, i.e., the successor who aims to take over leadership of a family firm. Secondly, this study integrates the Kasurinen model (2002), bringing forward new types of barriers (closely related to the role of the successor) and highlighting that they can intervene not only when the change takes place in the firm but even earlier, i.e., at the delicate moment of transition from the design phase to the implementation phase. The study also contributes to the development of the literature on family business, responding to the call of several authors (Salvato \& Moores 2010, Songini et al. 2013, Prencipe et al. 2014, Senftlechner \& Hiebl 2015, Helsen et al. 2017, Quinn et al., 2018) who have called for further empirical studies that take into account the specific context of family businesses. Finally, at the methodological level, this paper confirms the importance of longitudinal analyses and in particular of those carried out with an interventionist research approach, which aims to analyse the phenomena under investigation in-depth and to identify the reasons that can determine their evolution in the medium-long term, even if they are not very clear and evident.

Additional empirical research is needed to further analyze the binomial "MA" and "family businesses", and to better understand how family firms' uniqueness influences the MA processes and practices. Notably, MAC in family business should be considered a challenging research domain where scholars from both MA and family business studies are called to actively contribute. Further longitudinal case studies should be conducted in family firms that have successfully or unsuccessfully implemented a MAC process in order to analyze how and why the successor may act as a key agent throughout the different phases, identify other possible key agents and understand how they interact each other. Another area for future investigation concerns factors that may favour the launch and the implementation of a MAC process and the barriers to be overcome in a family-business context. Finally, keeping in mind that family businesses are not a homogeneous group (Daspit et al., 2018), quantitative research is needed to analyze if the different level of family involvement in family firms ownership, governance and management may affect MAC processes, influencing factors and possible barriers. 


\section{References}

Bracci, E., \& Maran, L. (2012). The role and use of management accouting systems (MAS) in family firms: a case study. Piccola Impresa/Small Business, 3, 129-153. https://doi.org/10.14596/pisb.35

Chrisman J. J., Chua, J. H., \& Sharma, P. (1999). Defining the family business by behaviour. Entrepreneurship Theory \& Practice, 23(4), 19-39. https://doi.org/10.1177/104225879902300402

Cobb, I., Helliar, C., \& Innes J. (1995). Management Accounting Change in a Bank. Management Accounting Research, 6(2), 155-175. https://doi.org/10.1006/mare.1995.1009

Craig, J. \& Moores, K. (2005). Balanced scorecards to drive the strategic planning of family firms. Family Business Review, 18(2), 105-122. https://doi.org/10.1111/j.1741-6248.2005.00035.x

Daspit, J. J., Chrisman, J. J., Sharma, P., Pearson, A. W., \& Mahto, R. V. (2018). Governance as a Source of Family Firm Heterogeneity. Journal of Business Research, 84, 293-300. https://doi.org/10.1016/j.jbusres.2017.12.041

De Massis, A., Chua, J. H., \& Chrisman, J. J. (2008). Factors preventing intra - family succession. Family Business Review, 21(2), 183-199. https://doi.org/10.1111/j.1741-6248.2008.00118.x

Giovannoni, E., Maraghini, M. P., \& Riccaboni A. (2011). Transmitting knowledge across generations: the role of management accounting practices. Family Business Review, 24(2), 126-215. https://doi.org/10.1177/0894486511406722

Heinicke, A. (2018). Performance measurement systems in small and medium-sized enterprises and family firms: a systematic literature review. Journal of Management Control, 28(4), 457-502. https://doi.org/10.1007/s00187-017-0254-9

Helsen, Z., Lybaert, N., Steijvers, T., Orens, R., \& Dekker, J. (2017). Management control systems in family firms: A review of the literature and directions for the future. Journal of Economic Surveys, 31(2), 410-435. https://doi.org/10.1111/joes.12154

Hiebl, M. R., \& Mayrleitner, B. (2019). Professionalization of management accounting in family firms: the impact of family members. Review of Managerial Science, 13(5), 1037-1068. https://doi.org/10.1007/s11846-017-0274-8

Hiebl, M. R., Feldbauer-Durstmüller, B., \& Duller, C. (2013). The changing role of management accounting in the transition from a family business to a non-family business. Journal of Accounting \& Organizational Change, 9(2), 119-154. https://doi.org/10.1108/18325911311325933

Hines, P., \& Rich, N. (1997). The seven value stream mapping tool, International Journal of Operations \& Production Management, 17(1), 46-64. https://doi.org/10.1108/01443579710157989

IMA - Institute of Management Accountants. (2006). Accounting for the Lean Enterprise: Major Changes to the Accounting Paradigm. Statements on Management Accounting.

Innes, J., \& Mitchell, F. (1990). The Process of Change in Management Accounting: Some Field Study Evidence. Management Accounting Research, 1(1), 3-19. https://doi.org/10.1016/S1044-5005(90)70042-X

Johnson, H. T. (2006). Lean accounting: to become lean, shed accounting. Journal of Cost Management, 20(1), 6-17.

Jönsson, S. (2010). Interventionism-an approach for the future?. Qualitative Research in Accounting \& Management, 7(1), 124-134. https://doi.org/10.1108/11766091011034307

Jönsson, S., \& Lukka, K. (2007). There and Back Again: Doing Interventionist Research in Management Accounting. In Chapman C. S., Hopwood A. G., Shield M. D. (Eds.), Handbook of Management Accounting Research. Elsevier, Oxford.

Kasurinen, T. (2002). Exploring Management Accounting Change: the Case of Balanced Scorecard Implementation. Management Accounting Research, 13(3), 323-343. https://doi.org/10.1006/mare.2002.0191

Kennedy, F. A., \& Brewer, P. C. (2005). Lean Accounting: What's It All About?. Strategic Finance, 87(5), 26-34.

Kennedy, F. A., \& Huntzinger, J. (2005). Lean accounting: measuring and managing the value stream. Journal of Cost Management, 19(5), 31-38.

Krafcik, J. F. (1988). Triumph of the Lean Production System. Sloan Management Review, 30(1), 41-52.

Le Breton-Miller, I. L., Miller, D., \& Steier L. P. (2004). Toward an integrative model of effective FOB succession. Entrepreneurship Theory \& Practice, 28(4), 305-328. https://doi.org/10.1111/j.1540-6520.2004.00047.x

Leotta, A., Rizza, C., \& Ruggeri, D. (2017). Management accounting and leadership construction in family firms. 


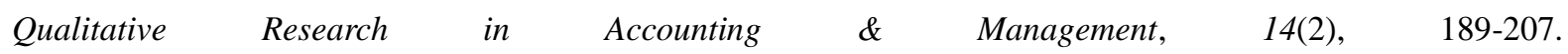
https://doi.org/10.1108/QRAM-09-2015-0079

Maskell, B. H. (2000). Lean accounting for lean manufacturers. Manufacturing Engineering, 125(6), 46-53.

Maskell, B. H., \& Baggaley, B. (2003). Practical Lean Accounting: A Proven System for Measuring and Managing the Lean Enterprise (1st ed.). Productivity Press, New York.

Maskell, B. H., \& Baggaley, B. L. (2006). Lean Accounting: What's It All About? Target, 22(1), 35-43.

Maskell, B. H., \& Kennedy, F. A. (2007). Why do we need lean accounting and how does it work?. Journal of Corporate Accounting \& Finance, 18(3), 59-73. https://doi.org/10.1002/jcaf.20293

Nordqvist, M., Hall, A., \& Melin, L. (2009). Qualitative research on family businesses: The relevance and usefulness of the interpretive approach. Journal of Management \& Organization, 15(3), 294-308. https://doi.org/10.1017/S1833367200002637

Patton, M. Q. (2002). Qualitative Research \& Evaluation Methods (3rd ed.). Sage Publications, California.

Prencipe, A., Bar-Yosef, S., \& Dekker H. C. (2014). Accounting research in family firms: Theoretical and empirical challenges. European Accounting Review, 23(3), 361-385. https://doi.org/10.1080/09638180.2014.895621

Quinn, M., Hiebl, M. R., Moores, K., \& Craig J. B. (2018). Future research on management accounting and control in family firms: suggestions linked to architecture, governance, entrepreneurship and stewardship. Journal of Management Control, 28(4), 529-546. https://doi.org/10.1007/s00187-018-0257-1

Quinn, M., Hiebl, M., Mazzotta, R., \& Veltri, S. (2020). Accounting for family and business overlaps. Journal of Management History, 26(2), 249-276. https://doi.org/10.1108/JMH-04-2019-0032

Salvato, C., \& Moores, K. (2010). Research on Accounting in Family Firms: Past Accomplishments and Future Challenges. Family Business Review, 23(3), 193-215. https://doi.org/10.1177/0894486510375069

Sánchez-Matamoros, J. B., Araújo Pinzón, P., \& Álvarez-Dardet, E. C. (2014). Management accounting change and agency in embedded situations. Spanish Journal of Finance and Accounting / Revista Española de Financiación y Contabilidad, 43(3), 241-265. https://doi.org/10.1080/02102412.2014.942153

Scapens, R., \& Bromwich M. (2001). Management accounting research: the first decade. Management Accounting Research, 12(2), 245-254. https://doi.org/10.1006/mare.2001.0159

Senftlechner, D., \& Hiebl, M. R. (2015). Management accounting and management control in family businesses: Past accomplishments and future opportunities. Journal of Accounting \& Organizational Change, 11(4), 573-606. https://doi.org/10.1108/JAOC-08-2013-0068

Sharman P. (2004). An overview of the field of family business studies: Current status and directions for the future. Family Business Review, 17(1), 1-36. https://doi.org/10.1111/j.1741-6248.2004.00001.x

Songini, L., Gnan, L., \& Malmi, T. (2013). The role and impact of accounting in family business. Journal of Family Business Strategy, 4(2), 71-83. https://doi.org/10.1016/j.jfbs.2013.04.002

Stergiou, K., Ashraf, J., \& Uddin, S. (2013). The role of structure and agency in management accounting control change of a family owned firm: A Greek case study. Critical Perspectives on Accounting, 24(1), 62-73. https://doi.org/10.1016/j.cpa.2012.09.007

Suomala, P., Lyly-Yrjänäinen, J., \& Lukka, K. (2014). Battlefield around interventions: A reflective analysis of conducting interventionist research in management accounting. Management Accounting Research, 25(4), 304-314. https://doi.org/10.1016/j.mar.2014.05.001

Womack, J. P. (2006). Value stream mapping. Manufacturing Engineering, 136(5), 145-156.

Womack, J. P., \& Jones D. T. (1996). Lean Thinking: Banish Waste and Create Wealth in Your Corporation. Simon \& Schuster.

Womack, J. P., Jones, D. T., \& Roos, D. (1990). The machine that changed the world. Simon \& Schuster, New York.

Zellweger, T. (2017). Managing the family business: Theory and practice. Edward Elgar Publishing, Cheltenham, UK.

Zoni, L., Dossi, A., \& Morelli, M. (2012). Management accounting system (MAS) change: field evidence. $\begin{array}{lllll}\text { Asia-Pacific Journal of Accounting \& Economics, } & 19(1), & 119-138 .\end{array}$ https://doi.org/10.1080/16081625.2012.668062 